\title{
Impacts of Green Electricity Markets in the United Kingdom, Germany and Finland
}

\author{
Hast A. ${ }^{1}$, McDermott L. ${ }^{2}$, Syri S. ${ }^{1}$ and Järvelä M. ${ }^{2}$ \\ ${ }^{1}$ Department of Energy Technology, Aalto University, PO Box 14100, FI-00076 \\ Aalto, Finland \\ ${ }^{2}$ Department of Social Sciences and Philosophy, University of Jyväskylä, \\ P.O. Box 35, FI-40014 University of Jyväskylä, Finland
}

Received: May 2014; Accepted: 27 May 2014

Publication: 30 July 2014

\begin{abstract}
In liberalized electricity markets, a wide variety of competing green electricity products are available to customers in addition to competition on tariff price. These voluntary products are marketed as environmentally friendly and claimed to support renewable energy production, new capacity building and offer other environmental benefits.

We review products in the UK, Germany and Finland and find that they encompass different mechanisms such as renewable sourcing, green funds or carbon offsetting. The interface between voluntary markets and renewable energy policies is especially studied. We assess if voluntary products offer additional benefits and identify possible problems like double counting or merely re-marketing hydropower produced in existing plants.

We analyse the transparency of products and their other sustainability impacts like energy efficiency improvements, local production, reduction of imported fuels or river restoration. We find that labels are important in increasing market transparency and setting criteria for green energy products.
\end{abstract}

Keywords: Green electricity products, certification schemes, voluntary markets, Eastern Finland.

Journal of Green Engineering, Vol. 4, 149-174.

doi: 10.13052/jge1904-4720.424

(c) 2014 River Publishers. All rights reserved. 


\section{Introduction}

In liberalized electricity markets customers can choose their electricity supplier and product according to their preferences. Price is not only criteria for many consumers and environmental aspects are also taken into consideration. As a result, many suppliers offer products that are marketed as environmentally friendly green electricity. Since the purchase decision is made by the consumer, labels and certification systems are needed.

However, people do not know what to do because of increased institutionalized individualism of society. People are only partly integrated into society's functional systems which makes them perceive their living environments more risky [1]. Therefore, it is important that consumers can rely on labelling and certification systems and that these systems continuously exist. Beck himself does not write about certificates. In societies functional systems are for example marriage, religion, steady employment, membership in groups etc. These systems support the individual and render the decision making easier because there is a norm to follow. The case study, which is presented later, shows that there has been a response to individualism, in North Karelia, in the meaning that new cooperation had emerged in response to the risk society and individualisation [2].

When reviewing green electricity the definition of it varies and there are several kinds of products available. Typically green electricity products mean that the energy is generated at least partly with renewable sources (green sourcing). Other kinds of mechanisms, such as green funds or carbon offsetting, can also be included to justify the claims of environmental benefits.

We study the voluntary green electricity products and especially their impacts in three European countries: the United Kingdom, Germany and Finland. There is also a case study of the city of Joensuu in Finland. The case study reviews energy production overall in the area of Joensuu, not just electricity. The studied countries are also Member States of European Union which has set binding renewable energy targets for the Member States [3]. Countries have also national laws and programs to reduce greenhouse gas emissions and to increase the share of renewables. For example feed-in tariffs for renewable energy and annual targets for the share of renewable in electricity mix are policies that do not only concern voluntary green electricity markets but all suppliers. It is not always clear what the additional benefits of green electricity products are, and there have been concerns that some suppliers only aim at meeting other binding targets with voluntary green energy products by allocating the already required renewable electricity to green tariff customers. 
It is also possible that electricity products are described as green for marketing purposes and especially hydropower, produced with power plants that have been built long time ago, is solely re-marketed as an environmentally friendly product. The real additional impacts are small if there is no need to build new renewable energy capacity.

The additional impacts of voluntary products in existing energy production structure can be difficult to assess for customers in particular. All suppliers do not provide transparent information about the impacts. Unclear or unreliable information makes the situation very difficult for the consumer in a society where societies' functional systems to do not efficiently support the individual in taking decision. [1,2]. Uncertainty and risks combined with unclear information can hinder renewable electricity markets. There are different kinds of certification and labelling schemes for green electricity products. We find that the role of labels is important both in setting criteria for products and also to increase market transparency by providing reliable information to consumers. However, based on the case study of the city of Joensuu in Finland it seems that renewable energy can proceed despite problems related to legislation, transparency, certification and labelling. Local initiatives on renewable energy need to be considered in the wider context of local economy and social dynamics.

This article is structured as follows. In the next section we review energy markets in the studied countries and especially the state of renewable energy. Existing targets, obligations and other policies concerning renewable energy are also described in section 2 both at EU and national level. Green energy products and certification schemes related to them in different countries are represented in section 3. Special attention is paid on assessing the impacts of green electricity products and how voluntary products support new renewable capacity. The possible problems in the interface with existing renewable energy policies are also assessed in section 3 and the case study of North Karelia is presented. Section 4 presents concluding remarks.

\section{Energy Markets and Renewable Energy in the United Kingdom, Germany and Finland}

There are obligatory national targets for the share of energy from renewable sources. According to the EU 2009 Directive, the share of renewable energy in gross final consumption of energy should be 38\% in Finland, 18\% in Germany and $15 \%$ in the UK by 2020 . Final energy consumption includes electricity 
but also transport and heating and cooling sectors, and there are no specific sectoral targets for electricity. [3]. However, the Member States were required to submit National Renewable Energy Action Plans (NREAPs) to the European Commission, and in the NREAPs the Member States set also sectoral targets concerning the development of renewable energy. The Member States have thus been required to set plans also for the electricity sector which has a significant contribution to the total targets for energy.

The EU 2009 Directive also requires that the Member States provide Guarantees of Origin (GO) for the electricity produced from renewable sources and that the same unit of energy is taken into account only once. Guarantees of Origin is a voluntary system for the producers. [3]. Yet, GOs are often utilized in the certification schemes to verify the origin of renewable energy. Main objective of the GO system is to increase consumer information and to avoid double counting i. e. to ensure that the same unit of renewable energy is not taken into account more than once. The implementation of the Directive varies and there is range of GO systems in place currently.

According to the EU 2003 Directive, the supplier has to provide customers with information on the sources from which the electricity is generated [4]. The requirement of the electricity disclosure has, however, been implemented in different ways in the national legislation of the Member States. In some countries it is allowed to include also differentiated products, like green tariffs, in the disclosure. [5]

The EU directives set goals that the Member States have to meet. The Member States can, however, freely decide how to achieve the goals. As a result, there are national laws and programs concerning renewable energy use and they include for example mandatory quota of renewable energy or mechanisms such as feed-in tariffs or eco-tax. These obligations and support systems can also have an impact on the green energy markets as described in section 3. Next we review the most relevant national programs in each studied country.

\subsection{National Programmes in the United Kingdom}

In the UK, the main support mechanism for increasing the generation of electricity from renewable sources, Renewable Obligation (RO), was initiated in 2002. It requires suppliers to buy a certain annual share of the electricity from renewable sources. Suppliers demonstrate the compliance with the obligation by Renewables Obligation Certificates (ROCs) and pay a penalty if the target is not met. ROCs are issued to electricity generators by Ofgem (the Office 
of Gas and Electricity Markets) relating to the amount of eligible renewable electricity generated. [6]

The Climate Change Levy (CCL) is a tax for non-domestic use of energy. Generators can receive an exemption from CCL if the energy is produced from approved renewable sources. This exemption is based on Levy Exemption Certificates (LECs). [7]. Energy savings are encouraged by the Carbon Emissions Reduction Target (CERT). CERT requires suppliers to make savings in the carbon emissions of household customers by promoting low carbon solutions for example. [8]. Formerly small-scale renewable energy production was incentivised by government grants but in 2010 the feed-in tariffs were introduced e.g. for solar photovoltaics [9].

In the UK, conventional thermal and nuclear power have an important role in the electricity production structure; over $70 \%$ of the electricity was produced with thermal and around $20 \%$ with nuclear. The share of electricity from renewable sources was approximately $8 \%$ in 2012. [10]. Regulation concerning renewable energy is undergoing a change as a part of the UK's Energy Market Reform (EMR). Reform is in the process of passing through the UK parliament and main elements of the proposal aim at stimulating investments in low-carbon technologies and to give producers incentives to provide reliable capacity. $\mathrm{RO}$ will be run in parallel with new system. [11]

\subsection{The German Renewable Energy Act}

The German Renewable Energy Act (Erneuerbare-Energien-Gesetz EEG) came into force in 2000 (updated in 2004, 2009 and 2012) to encourage renewable energy in Germany. The purpose of the EEG is to facilitate a sustainable development of energy supply especially from the climate and environmental view. The EEG aims to increase the share of renewable energy sources in supply and sets increasing targets for years 2020, 2030, 2040 and 2050. By the year 2020 the share should be 35\%. [12]

The support for renewable energy is based on the EEG and it defines the use of the main financial instrument, feed-in tariffs. There are also investment support for EEG-projects and tax exemptions for CHP production in Germany. The EEG includes a chapter concerning the rules of direct selling of renewable energy and prohibition of multiple sale of renewable energy. Renewable electricity, sold as a voluntary green electricity product cannot thus benefit from feed-in tariffs. [12]

In Germany the electricity production still relies heavily on coal and nuclear. In 2012 the share of lignite and hard coal was almost $45 \%$ and the 
share of nuclear power was around $16 \%$. However, the share of renewable electricity has increased significantly (from $3.6 \%$ in 1990 to $22.1 \%$ in 2012) due to strong support system. [13]

\subsection{Finland}

In Finland the electricity production structure includes a large share of nuclear and hydropower, almost fifth of the electricity generated is from hydropower and one fourth by nuclear power. In the NREAP of Finland, the target for electricity is to increase the share of renewable electricity in final consumption to $33 \%$ by 2020 . In 2005 , this share was $27 \%$. [14]

Feed-in tariffs for biogas and wind power were initiated in Finland in 2010. They came into force in 2011 and tariff guarantees $83.5 € / \mathrm{MWh}$ for 12 years for wind power (higher tariff until 2015). The tariff is guaranteed up to 2500 MW total regarding new wind capacity. [15]. At the moment, there are around $7500 \mathrm{MW}$ of new projects under consideration. Some of them are however off-shore wind projects which are unlikely to be started without separate offshore tariff. $[11,16]$. In the National Energy and Climate Strategy, the target for wind power is $6 \mathrm{TWh}$ by 2020 when it is estimated that the electricity consumption is approximately $94 \mathrm{TWh}$ in 2020 in the baseline.[17]

Power plants that use wood-based fuels to produce electricity can also receive feed-in tariff. The support for electricity production with wood chips depends especially on the taxation of peat and the emission allowance of peat. The variable support is in the range of 0 to $18 € / \mathrm{MWh}$ of electricity. [15]

The legislation concerning the reporting and verification of the origin of electricity was recently changed in Finland. One important aim of the law proposal was to prevent double counting of renewable energy. [18]

\section{Green Electricity Products and Certification Schemes}

In this section the different types of green electricity products and their properties are described. Especially the different kinds of mechanisms to support new renewable energy capacity are studied and their effectiveness are assessed and compared. Possible problems and challenges in the interface between voluntary green electricity markets and renewable energy policies are also described. The additional impacts of voluntary markets are studied and the role of certification schemes to guarantee them are considered.

The definition of green electricity is not always clear and there is a chance that environmental aspects are used for marketing reasons. There can also be 
different views on what kind of impacts the voluntary markets should have. Generating renewable energy from existing plants and selling it to specific consumer segments do not have desired environmental impacts because it only improves the environmental record of green energy customers and declines the environmental record of other customers. It can be complicated to assess the environmental impacts of voluntary products; customers often are not interested or do not have enough information to do a thorough assessment of the impacts. Yet, making contribution in the electricity production structure is preferred by consumers. This is why the role of labelling schemes are important in guaranteeing additional environmental impacts. Labels can also increase market transparency by providing customers more reliable and objectively assessed information about the products and their impacts. Labels launched in an early phase can have significant advantage to set standards for the whole market. [19, 20]

Eco-labels may take into consideration different types of environmental impacts and there are differences between labels in how demanding the requirements are. Many labels prioritise the impacts on new renewable energy capacity and include criteria concerning for example the age of power plants or minimum amount of investments in new capacity. [21-25]. Labels can also require other additional environmental actions such as funds for renewable projects or improving energy efficiency [26]. They can also set sustainability criteria for the energy production and charge for the usage of the label. This money can be used for example to improve the ecological state of water systems [27].

Green energy can also have other than environmental impacts. In this section we give a couple of examples of the social and economic impacts in particular based on the case study. Social and economic impacts can be related to the overall development of society where vital areas of society have become unsure. This is called the risk society by Ulrich Beck [1]. According to Beck [1] the current society creates risks that previous generations have not faced before. These risks are global and created by society itself; climate change is one example of this type of risk. Simultaneously, some of the more traditional risks of the industrial society (such as unemployment) also prevail or may even be aggravated adding to the overall need for societal mitigation. [1]

Beck's [1] risk society theory is relevant to the case study in particular because the area of Joensuu has been struggling with deterioration of local economy and problems related to local public policy. As a consequence people have continued moving out of the area of Northern Karelia. However, the last two years in the area of North Karelia have been slightly on the positive side 
when considering migration, so there has been some improvement in local development [28].

\subsection{The United Kingdom}

In the UK the variety of different kinds of green electricity products is wide but demand for green energy products has remained modest [29]. Common elements like green sourcing, green funds or carbon offsetting can be found in most of the products. Products can also be classified according to the share of energy from different renewable sources (large hydro, other renewable). Recently five of the big six energy companies in the UK stopped offering green tariffs to new customers [30].

Green sourcing means that the sold green electricity is at least partly matched by purchases of renewable energy by supplier. According to the study by Hast et al. [29] green sourcing is commonly included mechanism but it is very rare that all energy comes from additional renewable sources. Many tariffs state that green tariffs are from renewable sources but suppliers may simply assign some of the already required renewable energy to green tariff customers and reduce the amount they provide to other customers. It does not then have any influence on the overall energy mix. [31]

There have been concerns that some suppliers only aim at fulfilling the minimum RO requirements and selling renewable energy utilized to meet requirements also as voluntary green energy product. In this way the environmental benefits of renewable energy arecounted twice because assigning the already required renewable energy to green tariff customers does not provide additional environmental benefits above the RO system. If this same renewable energy is also utilized to avoid Climate Change Levy from non-domestic use of energy, there is a chance of triple counting of environmental impacts. In order to make sure that double or triple counting do not happen, it would be important that suppliers retire both ROCs and LECs. However, only three suppliers have retired part of their ROCs. [29]. Assumingly the suppliers pass the costs caused by the RO to customers [6]. Thus all electricity customers already pay for the renewable energy in their electricity bills even if they have not bought green energy and it is therefore important to consider the real additionality of voluntary products above legally set obligations.

Green electricity products often include green funds and they are typically used to support projects and research on renewable energy. Carbon offsetting is not as frequently used mechanism but it appears in couple of products. Carbon offsetting means that unavoidable emissions are compensated by 
paying someone else to make an equivalent carbon dioxide saving elsewhere. These actions can be for example increasing energy efficiency and gaining emission reductions that way. [29]

Additional benefits to green tariff customers can also be promised for example by offering discounts on energy saving products like light bulbs and energy efficient kettles. Home energy survey, information on energy efficiency and helping schools to reduce their emissions are also included in green tariffs. Also for example investments in renewable energy projects (e.g. waste and hydropower) and support to community owned small-scale wind power production have been promised. [32]. The real impacts of several different types of additional benefits can, however, be difficult for consumers to assess and compare. All suppliers do not provide detailed information about the real impacts of different projects, which reduces the transparency of the products. The abstract nature of electricity has been identified as one possible explanation for consumer passivity [33] and thus these more concrete benefits of the green tariffs can also be useful in the marketing.

\subsubsection{Green energy supply scheme}

There have been some non-binding guidelines on green energy in the UK but most of them have been withdrawn [34]. For example Ofgem and Energy Saving Trust developed a star rating scheme for green energy products in 2007 in order to give customers clear and accurate information on the options [35]. However, there has been a lack of comprehensive certification scheme for green electricity products for a long time and there have been green tariffs with misleading and confusing claims. To verify the claims of suppliers and to help customers to recognize the products with genuine environmental benefits, Ofgem launched a certification scheme called Green Energy Supply Scheme in 2010. Products are assessed by an independent panel of experts. [36]

Green energy products certified by Green Energy Supply Scheme are guaranteed to match renewable electricity purchases and also to provide additional benefits. Additional benefits can be delivered in a variety of ways: green funds, energy efficiency measures and carbon offsets. Money can be donated to charity or to funds that invest in new renewable projects that is usually in community scale. Green fund projects carried out have been for example installing solar panels on primary schools, installing a wind turbine at a community college or fitting a ground source heat pump at a museum. Additional benefits have also been achieved by delivering energy efficiency improvements that are outside the scope of other regulations like CERT. Suppliers have e.g., provided Standby Savers to customers on the green tariffs 
and implemented a programme of energy saving measures for customers. Carbon offsetting projects are for example supporting wind power project in China or replacing fossil fuel-fired thermal power plants with hydropower in Brazil. [26]

Currently there is only one green tariff, certified in Green Energy Supply Scheme, available for new domestic customers [37]. According to Consumer Futures, this has led to confusing markets since other companies continue to market their tariffs as green [38].

\subsection{Germany}

The demand for green electricity products is relatively high in Germany. Typically products source mainly from renewable energy sources and they can be classified according to their fuel mix. Three main categories are often used: large hydro, blends of renewables and CHP and 100\% renewables $[20,39]$. Products with a large share of hydro are very common and the power often originates from abroad. The origin is typically Norway or other Scandinavian countries but power can also be imported from Austria and Switzerland. [29, 40].

In order to avoid double counting of renewable energy, the EEG forbids multiple selling of renewable energy so renewable electricity that has been remunerated under the EEG, cannot be marketed as green power. [12]. Yet, other kinds of problems may arise in the interface between the EEG and voluntary green electricity markets. Since the EEG sets a minimum price for renewable energy in Germany through feed-in tariffs, the producers will sell the renewable energy to suppliers of green products only if they earn more money in that way. This would increase the price of green energy products and it is likely that fewer customers would then be willing to buy the products. In order to keep the prices of green energy low, many suppliers purchase especially hydropower from abroad, where it could not be used under the EEG in any case, and sell the imported energy to green energy customers in Germany. [41-43]

The problems of high share of imported hydropower in green energy products have been discussed and criticized in several sources. Environmental impacts have been questioned since hydropower often originates from already existing plants. [44-46]. In many countries, like Norway, the existing capacity is large and it has been built several years ago. Thus, the existing capacity is large enough to fulfill the demand of green energy also in the future and new plants are not needed. It can then be very difficult to estimate the real impacts 
of voluntary products on the electricity production structure both in Germany and abroad, which reduces the transparency of the products significantly. It is also important to note that even if hydropower is classified as a renewable energy source, it can still have other environmental issues such as harming the ecosystem of the water system.

\subsubsection{Labelling schemes for green electricity products in Germany}

There are several labelling and cerfitication schemes for green energy in Germany. The first scheme was German TÜVs and it was launched in 1998 [19]. We study in more detail a couple of well-known labels: Grüner Strom Label (GSL), ok-power, TÜV Nord and TÜV Süd. We find that there are differences between labels in the requirements and in their bindingness. For example the requirements concerning the age of power plants and required investments in new capacity vary. It is also important to note that some schemes allow electricity from combined heat and power production (CHP) plants to be included in green tariffs. In 2011 around $80 \%$ of the fuels used in CHP production were either gas or coal in Germany [47] which is why the emissions of electricity from CHP plants can be relatively high.

Grüner Strom Label (GSL) has two categories: GSL-Gold and GSL-Silber. GSL-Silber certified products are allowed to include up to 50\% of electricity from CHP production. GSL requires that certified products offer environmental benefits that otherwise would not occur. Certain amount of money per each sold kilowatt hour has to be used to support new renewable facilities or to fund innovative projects that encourage energy transition in other ways. Investments should be done in solar, biomass or wind projects in Germany but projects in developing countries can also be supported. New plants can, however, be co-funded and it is possible that they will be utilized under the EEG. Innovative projects can include for example small-scale wind and solar projects, recycling and energy efficiency improvements. [21]. There are 60 suppliers, both nationwide and local, whose green electricity product is GSL-certified [48]. Altogether there are over 800 green energy suppliers in Germany [49].

The "ok-power"-label includes criteria concerning the age of the power plants in order to encourage the building of new renewable capacity. At least third of the green energy should originate from plants that are no more than six years old and the second third of electricity should come from plant less than 12 years old. There are also requirements about ecological aspects of producing energy and the plants must therefore fulfil also environmental 
requirements. Earlier ok-power certified products could include $50 \%$ of energy that was produced with gas-fired CHP plants with high efficiency but the option of including electricity from CHP plants was removed in 2013. [50]. There are over 90 energy suppliers that are selling ok-power certified products [51].

TÜV Nord and TÜV Süd are also well-known labels for green electricity products in Germany. TÜV Süd has different categories for green energy products. There are two categories, EE01 and EE02, for energy $100 \%$ from renewable sources. In EE01 category it is required that at least $30 \%$ of the energy must come from new plants or that building of new plants is supported. In category EE02 it is required that the sold energy must be timely matched to the produced energy every 15 minutes. In both categories some amount of the premium has to be used for either supporting the building of renewable energy or to other environmental actions. Electricity that partly originates from CHP plants can also be labelled with TÜV Süd certificate. Categories UE01 and UE02 require that at least 50\% of the energy originates from renewable sources but as much as $50 \%$ of the energy can come from CHP plants that use fossil fuel. [23, 24].

TÜV Nord certificate requires thatat least $33 \%$ of energy should originate from plants that are not older than six years or that the plant has been upgraded less than six years ago to produce the amount of labeled green energy. Alternatively to this requirement, fixed amount of money per sold kilowatt hour can be invested in the building of new plants. Products can include electricity from CHP plants. [22]

\subsection{Finland}

In Finland green energy products include different mechanisms to support renewable energy production. Green funds are included in a couple of products and money is used to support research and building of renewable energy capacity and also to support other environmental actions, such as energy saving and energy efficiency projects. There are also few companies that offer customers the possibility to buy shares and then buy electricity on a lower price than customers who do not own shares. These products typically have good transparency and they also have a positive impact on new capacity. [29]

The majority of the products available in Finland include green sourcing mechanism and the renewable electricity is typically produced by hydro or wind. The electricity can, however, be bought from the market and produced with plants that have been built a long time ago. It can therefore be unclear if there are any additional impacts on new capacity. Suppliers do not always 
provide detailed information on how the premiums are used which makes it even more difficult to assess the impacts of green sourcing products. Compared to other mechanisms, the transparency and impacts on new capacity can be relatively weak in green sourcing products. There are, however, also suppliers that provide transparent information for example about the investments in new plants. [29]

The legislation concerning the origin of electricity was recently changed in Finland and one important issue was to update legislation to prevent double counting of renewable energy. It was proposed that there should be only one method to prove the origin of renewable energy because several coexisting systems created a chance of double counting. The new legislation came into force in July 2013 and now the law accepts only one method to verify the origin of renewable energy. [18]. Earlier it was possible to sell renewable energy twice by selling the guarantees of origin for renewable energy but also use the same renewable energy in marketing. [18, 52, 53]. This may have influenced consumers' attitudes towards green electricity products.

\subsubsection{EKOenergy}

EKOenergy label is a European environmental label for green electricity. It sets sustainability criteria for electricity production and also requires new investments. In Finland the label is managed by the Finnish Association for Nature Conservation and suppliers pay a certain amount of money per sold $\mathrm{kWh}$ of EKOenergy to the EKOenergy Climate Fund. This money is used to reduce the harmful effects of hydropower and various projects to river restoration and improving the ecological state of water systems have been funded. The label sets sustainability criteria for hydro, wind and wood-based renewable energy production. These criteria take into consideration e.g. effects on biodiversity and landscape, possible damages to fish and bird populations. [27]. Currently there are 12 licensed sellers of EKOenergy in Finland [54]. In total, there are over 30 electricity products advertised as green $[55,56]$.

In Finland and other Nordic countries the energy structure relies strongly on the hydropower production. Majority of the hydropower is built before 1980's and the possibilities for new capacity are limited because of environmental reasons. Hydropower can have environmental issues and harm the ecosystem of the water system and e.g., disturb the fish population. It can also reduce the recreational and cultural value of the area and thus be objected by local residents. 


\subsubsection{Case study: Eastern Finland}

This case study is part of larger project where four cities were researched in Finland and two cities in Texas in the U.S.A. In Finland the cities were Joensuu, Imatra, Vaasa and Espoo. In the U.S. the cities were Austin and San Antonio. By way of example concerning the social dimension and dynamics of expanding renewable energy this paper presents only the case Joensuu in Finland. The research questions for all case studies were: How did renewable energy become more common? Why did renewable energy become more common? In other words this case study is about the societal prerequisites of increasing renewable energy.

Del Rio \& Burguillo [57] conclude that studies on local renewable energy often concentrate on employment. Studies should include more intangible and tangible effects and look for diversified income generation to the local population. Madlener \& Vögtli [58] and Madlener [59] mentioned the importance of local acceptance, the importance of politics, the beneficial effect of renewable energy to stakeholders and local public policy and the existence of previous know-how on the chosen energy technology or fuel in case studies. In this case study benefits on local public policy are mentioned but also the meaning of the forest to local identity, the use of locally produced wood which leads to diversified income generation and increase of other resources e.g. intangible knowledge.

The research itself was conducted mostly by an empirical approach. According to Del Rio \& Burguillo [57], making empirical research in different geographical areas is important. By researching local benefits empirically solutions to problems that renewable energy investors face could be solved. These include problems with getting the right permits, problems in political willingness and bureaucracy. The analysis was conducted by using qualitative research methods, in particular content analysis. The interviews were searched and coded by using the research questions and hints from the theoretical framework of risk society [1]. This research is based on abductive reasoning. The analysis is based not only on the theory but also on previous information and hints from the research data $[60,61]$. The research data was collected by interviewing people and by reading documents as supporting information. The supporting document are: the growth strategy of Joensuu [62], the international strategy of Joensuu [63], the bioenergy program of North Karelia [64], the climate and energy program of North Karelia 2020 [65] and the economic strategy of Joensuu 2013-2015 [66]. Documents written by the provincial government of North Karelia were chosen because during the interviews 
(e.g. quote 1) it became clear that cities and towns in North Karelia are in cooperation when it comes to economic development.

1. There is a lot of cooperation here and it is understood that Joensuu and the province of North Karelia are dependent on each other.

The provincial government of North Karelia, official, 27 years old

There were six interviews from North Karelia which lasted between 45 minutes to 1.5 hours. The interviews were conducted in Finnish, the quotes have been translated. The people interviewed were experts in the area of renewable energy. The interviewed people were chosen by asking the provincial government of North Karelia for people who are experts in the area of renewable energy.

There are five things that seem to have created the prerequisites for renewable energy in the city of Joensuu: 1) rising energy prices, 2) regional policy, 3) cooperation, 4) expertise and 5) small and medium sized actors. In other words knowledgable people with a common goal who are ready to work together in front of a threat of rising energy prices. So it seems that in response to the risk society and problems in local public policy [1] things could be solved by cooperation. However, there has to be the right mind set for cooperation to happen. It seems that Joensuu has a lot of small and medium sized actors which could indicate that people are more active because they cannot rely in large industries. This could lead to a willingness to actively improve things. Joensuu is also a city that has a high level of expertise; this could indicate that education is important for innovative actions. According to the interviews (e.g. quote 2) and the fact that fossil oil is expensive, there is also the issue of rising oil prices which started rising at the end of the 1990s [67]. This situation forced people in the area of Joensuu and North Karelia overall to search for another option because heating was getting expensive. It seems that a clear benefit is what drove renewable energy forward, in this case the benefit was saving money by using a local resource, wood, that is very abundant in the area of Joensuu and North Karelia.

2....we have a lot of forests and we have used a lot fossil oil that is brought from far distances. The decision took a while to make, we made calculations and oil seemed expensive. Based on this the decision was easy to make.

Chairman of a heat Co-op in the area of Joensuu

It seems that when the possibilities of renewable energy were noticed it became a matter of regional policy in the last few years. According to many 
interviews (e.g. quote 3) and supporting documents [62, 64-66] renewable energy is important in regional policy because Joensuu is interested in the financial possibilities of the forest industry and Joensuu seems to have the experience, knowledge and expertise to utilizing forests. Joensuu also has the following forest research centers: European Forest Institute, The Finnish Forest research institute (METLA) and The Finnish Forest Center. Joensuu also has education on every level of forestry. There are education programs in bioenergy and forestry and many education institutes offering vocational training up to University degrees. In addition, three people interviewed were from families where the parents worked in the forest industry or were forest owners. It seems that there could be a cross-generational connection to the forest industry when reviewing the interviews. This could be an indication of tacit knowledge of forestry in the area of North Karelia and an indication of social identity related to forest livelihoods and bioenergy (quote 4 and 5). Tacit knowledge [68] is a term used for knowledge that is a long term asset to the entity but it has no physical existence. Tacit knowledge is also related to social identity. Social identity means that the individual's self-concept is derived from memberships to social groups [69]. So it seems that there is a lot of knowledge on forestry in North Karelia and in the Joensuu area and it could be a part of North Karelian social identity. When looking at the quotes one can also see that there are people from different generations with a forest background which indicates the cross-generational connection.

3. We have well trained people. We see that wood energy and utilizing wood energy is one of the few real money bringers to this area. It makes it very motivating. It would be very difficult to create an industry in some other field of trade that would bring so much revenue that the energy sector can offer... Bioenergy is seen as strength, a growing possibility. It is our gold mine or area of expertise which can bring economic benefit to this area

Forest Center of Finland, bioenergy expert, 59 years old.

4. I grew up in in a small country village and the forest industry was familiar through my parents livelihood, people around me and my own work as an adult

Ex-Entrepreneur, teacher and expert in bioenergy, The polytechnic of North Karelia, about 40 years old

5. The forest is a resource that is a basic necessity. My father utilized the forest in an economic sense and he owned forests. Through my father's 
employment I have also been taking care of forests and working in forests.

The provincial government of North Karelia, 27 years old

Bioenergy seems to be an interest on the level of regional and city policy. Bioenergy is mentioned in the supporting document [62] as one of the three main areas of financial development in Joensuu. These three areas are firstly forest bioenergy, secondly technology, materials and information and communication technology (ICT) and thirdly the creative industry and visual arts [62]. Bioenergy was also mentioned in the climate and energy strategy of North Karelia [65], the provincial government of Northern Karelia has a separate bioenergy strategy plan [64] and bioenergy was mentioned as being important in all the interviews. However, for the time being bioenergy has not solved all problems related to employment and the economy in Joensuu and the area of North Karelia. Yet, bioenergy is seen as a real possibility for regional economic growth [66].

Presently, bioenergy and industries related to bioenergy and forestry employ about 6000 people in 500 companies: The annual revenue of these companies is about 1.7 billion euros. [62]. Positive effects of bioenergy have been found also in previous research. Del Rio \& Burguillo [70] found positive effects on the local economy in biodiesel production because the production of biodiesel was local. The same positive effect was not found in the case of PV solar or wind because the production of wind turbines, solar panels etc. was not on a local level and the fuel for solar and wind does not need to be produced. [70] According to the interviews, in the case of North Karelia wood chips are locally produced. According to the interviews (quote 6 and 7), there seems to be traditionally more small and medium sized actors in the area of North Karelia and Joensuu and the population is small; people know each other. There seems to also be a high level of cooperation between different actors in Joensuu [63]. This could be an indicator of social capital between people working in bioenergy. There is also an openness when it comes to the countries and people abroad. According to supporting documents [63] the city of Joensuu and other actors are actively networking with countries abroad, especially Russia [63]. Cooperation seems to be a beneficial factor when it comes to dealing with intangible threats like climate change mentioned by Beck [1]. So it seems that the degradation of social capital which Putnam [71] has mentioned is a negative factor when dealing with an intangible threat like climate change. It would seem that to create cooperation social capital is needed; there can be no cooperation or effort in society without people. The provincial government 
was mentioned in many interviews (e.g. quote 8) as a connecting force when creating a common will. So it seems that that a leader is needed who will combine the knowledge but not enforce their own authority and opinions.

6. There are small and medium sized actors here who consider members of the network important... We have some big industries but none of them are in the position that they would have dominated the local economy.

The provincial government of North Karelia, 27 years old

7. ... it could be the small size of this area. We are a small and compact province, we know each other and information travels quickly and networks are born naturally. Nobody has an interest to be angry with each other because people know each other.

The provincial government of North Karelia, 27 years old

8. The provincial government of North Karelia has made it possible to create a common will

Forest Center of Finland, bioenergy expert, 59 years old

Hence, it seems that renewable energy can proceed even in a situation where legislation, different labels and certification are not perfect. In the case of Joensuu the motives to increase bioenergy have been clearly related to rising energy prices and local public policy. Solutions that positively affect the local area and its economy seem to be a very good option when tackling problems related to climate change i.e. reducing greenhouse gases.

\section{Discussion and Conclusions}

In liberalized electricity markets customers can choose their electricity supplier and contract freely according to their preferences. Since environmental aspects are also often taken into consideration by many customers, suppliers are not only competing on price anymore. Several types of voluntary green electricity products are available for customers in the UK, Germany and Finland, and problems may arise in the interface between voluntary green energy markets and renewable energy policies.

There are EU targets and national legislation concerning renewable energy. For example in the UK, suppliers are obliged to include a specific share of renewables in the fuel mix. There are also other instruments such as feed-in tariffs to encourage the production of renewable energy. The interface between voluntary green energy markets and renewable energy policies is not always simple and problems like double counting the environmental benefit may 
arise. Therefore in assessing the additional benefits of voluntary markets, it is important to take into consideration whether products have real impacts above binding obligations. According to our study, the lack of comprehensive legislation can make the double counting of the environmental value possible like in the UK and earlier also in Finland. Yet, even if double counting is prevented like in Germany, there can still be a risk of other unwanted effects like high share of imported hydropower in the green electricity products. According to Beck unclear information complicates the situation for the individual since the support of societies functional systems do not exist in the same way as they used to $[1,2]$. Double counting makes it difficult for a consumer to make decisions because the information is not reliable. This combined with institutionalized individualism makes the situation difficult for the consumer.

There are also optional green energy labels available for the products. These schemes can set additional criteria for the products concerning for example the age of the plants or investments in new capacity. Other additional environmental benefits can be required or the usage of the label can be charged and money used to support environmental projects. There are also more detailed requirements concerning the energy production and sustainability criteria can be set e.g., for hydro or wind power production. There is variation in the possibility to include electricity from CHP plants in green energy products and we found that in Germany in particular the acceptance of CHP varies between labels.

We found that there are several types of green electricity products including different kinds of mechanisms to provide environmental impacts. The definition of green electricity is not always clear and products can include different kinds of mechanisms, such as green sourcing or green funds. It can be complicated, especially to the consumers, to assess what kind of impacts the purchase of green energy has on the existing energy production structure and whether the voluntary products offer real additional benefits above legally set obligations. We found that all suppliers do not provide detailed information on the use of price premiums or on the influence on new renewable capacity. The role of certification schemes is also important in increasing market transparency since labels can provide more clear and reliable information to the consumers. This further shows how the aspects of the risk society and institutionalized individualism complicate the individuals life. The use of price premiums and environmental effects of renewable electricity are not reliable sources of information for the consumer. This further complicates the situation for the active individual who wants to solve risks of the risk society by buying renewable electricity. 
Furthermore, we have demonstrated how renewable energy can proceed if it has a positive effect on local public policy. In the city of Joensuu renewable energy has proceeded because it has supported local public policy. It has solved problems related to rising energy production costs and given possibilities to the area to search for new areas of economic development. The forest industry and bioenergy have traditionally had a positive effect on economic development in the area of Joensuu and in the area of North Karelia. Now bioenergy is seen as possibility that could help the area to find an answer to the problems related to the emerging risk society. In this case this implies specific measures for the transformation of industrial production. These measures have both direct and indirect positive impact on local employment. Therefore renewable energy can have a broader meaning than just reducing greenhouse gas emissions.

\section{References}

[1] Beck, U. (1992): Risk society: towards a new modernity / Ulrich Beck; translated by Mark Ritter. London: Sage

[2] Beck, U. (2001): Individualization: institutionalized individualism and its social and political consequences / Ulrich Beck and Elisabeth BeckGernsheim. Reprinted in 2008. Los Angeles: Sage Publications, 2008

[3] Directive 2009/28/EC of the European Parliament and of the Council of 23 April 2009 of the promotion of the use of energy from renewable sources and amending and subsequently repealing Directives 2001/77/EC and 2003/30/EC, Official Journal of the European Union 140/16, 5.6.2009

[4] Directive 2003/54/EC of the European Parliament and of the Council of 26 June 2003 concerning common rules for the internal market in electricity and repealing Directive 96/92/EC, Official Journal of the European Union 176/37, 15.7.2003

[5] http://www.reliable-disclosure.org/electricity-disclosure/ visited 8 July 2013

[6] https://www.gov.uk/government/policies/increasing-the-use-of-lowcarbon-technologies/supporting-pages/the-renewables-obligation-ro visited 3 April 2013

[7] http://chpqa.decc.gov.uk/climate-change-levy-exemption-certificateslecs-for-electricity-produced-by-good-quality-chp/ visited 3 April 2013

[8] http://www.decc.gov.uk/en/content/cms/funding/funding_ops/cert/cert. aspx visited 9 November 2012 
[9] http://www.decc.gov.uk/en/content/cms/meeting_energy/Renewablee_en r/feedin_tariff/feedin_tariff.aspx visited 9 November 2012

[10] http://epp.eurostat.ec.europa.eu/portal/page/portal/statistics/search_data base visited 3 April 2014

[11] Syri, S., Cross, S. (2013): Weak EU emissions trading with strong renewables obligation compromises long-term $\mathrm{CO}_{2}$ mitigation, Proceedings of the $10^{\text {th }}$ International Conference on the European Energy Market, Stockholm, 27-31 May 2013

[12] BMU (2012): Act on granting priority to renewable energy sources (Renewable Energy Sources Act - EEG), Bundesministerium für Umwelt, Naturschutz und Reaktorsicherheit

[13] AG Energiebilanzen (2013): Bruttostromerzeugung in Deutschland von 1990 bis 2012 nach Energieträgern, Stand: 14 Februar 2013

[14] MEE, Ministry of Employment and the Economy (2012): Finland's national action plan for promoting energy from renewable sources pursuant to Directive 2009/28/EC

[15] Finlex (2010): Laki uusiutuvilla energialähteillä tuotetun sähkön tuotantotuesta, 1396/2010: http://www.finlex.fi/fi/laki/ajantasa/2010/20101396

[16] Salo, O., Syri, S., (2014): What economic support is needed for Arctic offshore wind power? Renewable and Sustainable Energy Reviews 31, 343-352

[17] MEE, Ministry of Employment and the Economy (2013): National Energy and Climate Strategy

[18] Finlex (2013): Hallituksen esitys eduskunnalle laiksi sähkön alkuperän varmentamisesta ja ilmoittamisesta annetun lain muuttamisesta, HE 37/2013: http://www.finlex.fi/fi/esitykset/he/2013/20130037

[19] Truffer, B., Markard, J., Wüstenhagen, R. (2001): Eco-labeling of electricity - strategies and tradeoffs in the definition of environmental standards, Energy Policy 29, 885-897

[20] Bird, L., Wüstenhagen, R., Aabakken, J. (2002): A review of international green power markets: recent experience, trends, and market drivers, Renewable and Sustainable Energy Reviews 6, 513-536

[21] GSL (2012): Grüner Strom Label e.V. Criteria 2012

[22] TÜV Nord (2011): "geprüfter Ökostrom" nach dem TÜV NORD CERT Standard A75-S026-1, Kriterienkatalog (Bilanzierungsjahr 2011)

[23] TÜV Süd (2008): Kriterienkatalog: UE01 (version 10/08), CMS Standard 84

[24] TÜV Süd (2004): Kriterienkatalog UE02 (Stand: 01/04) zum CMS Standard 85 
[25] http://www.ok-power.de/ok-power-label.html visited 4 April 2013

[26] http://www.greenenergyscheme.org/ visited 5 June 2013

[27] http://www.ekoenergia.fi visited 4 April 2013

[28] SVT (2012). Statistics Finland (SVT): Muuttoliike. ISSN=1797-6766. 2012. Helsinki: Statistics Finland.

[29] Hast, A., Syri, S., Jokiniemi, J., Huuskonen, M., Cross, S., (2014): Review of green electricity products in the United Kingdom, Germany and Finland, submitted manuscript

[30] The Guardian (2013): Five of "big six" energy companies drop green tariffshttp://www.theguardian.com/environment/2013/jul/23/bigsix-energy-companies-green-tariffs

[31] http://www.energysavingtrust.org.uk/Electricity/Buying-green-electricit y\#3 visited 5 June 2013

[32] http://www.consumerfocus.org.uk/get-advice/energy/households/ energy-tariffs-explained/green-tariffs visited 5 June 2013

[33] Salmela, S., Varho, V. (2006): Consumers in the green electricity market in Finland, Energy Policy 34, 3669-3683

[34] Willstedt H., Bürger, V. (2006): Overview of existing green power labelling schemes, A report prepared as part of the EIE project "Clean Energy Network for Europe (CLEAN-E)", Öko-Institut

[35] Ofgem (2007): Star Rating Scheme for Green Energy Deals, R/23

[36] Ofgem (2010): New label launched for certified green electricity - press release, $\mathrm{R} / 6$

[37] http://www.greenenergyscheme.org/join/find-certified-green-tariffs/fulltariff-listing/ visited 1 April 2014

[38] Consumer Futures (2014). Improving Consumer Protection in the Green and Renewable Energy Offers Market.

[39] Wüstenhagen, R., Bilharz, M. (2006): Green energy market development in Germany: Effective public Policy and Emerging Customer Demand, Energy Policy 34, 1681-1696

[40] Stiftung Warentest (2012): Nicht jederTarif ist grün, test 2/2012

[41] Wagner, E. (2008): Ökostrom-Tarife Was sind diese, was bewirken diese?

[42] Leprich U. (2008): Fokus Ökostrom: Bestandsaufnahme und Perspektiven, Kurzstudie im Auftrag von Greenpeace e.V

[43] Wüstenhagen, R., Bilharz, M. (2004): Green Energy Market Development in Germany: Effective public Policy and Emerging Customer Demand, IWOe Discussion Paper No. 111

[44] http://green.wiwo.de/flexstrom-und-co-wie-okostrom-discounter-green washing-betreiben/ visited 18 June 2013 
[45] http://www.welt.de/finanzen/verbraucher/article12890222/Nicht-alleswas-gruen-ist-ist-wirklich-Oekostrom.html visited 18 June 2013

[46] http://www.test.de/Strom-Der-Wechsel-lohnt-1132700-1132740/ visited 18 June 2013

[47] http://www.umweltbundesamt-daten-zur-umwelt.de/umweltdaten/public /theme.do?nodeIdent=2323 visited 4 April 2013

[48] http://www.gruenerstromlabel.de/english/our-label/ visited 27 March 2014

[49] http://www.stromauskunft.de/oekostrom/oekostrom-anbieter/ visited 27 March 2014

[50] EnergieVision e.V. (2012) Criteria for ok power labelling of ecoelectricity, version 7.2

[51] http://www.ok-power.de/alle-zertifizierten-produkte.html visited 27 March 2014

[52] http://www.ekoenergia.fi/uutiset/yle-vihrean-sahkon-kaksoismyyntimahdollista visited 18 June 2013

[53] http://yle.fi/uutiset/ekoenergian_alkupera_askarruttaa_-_valvonta_ei_ ulotu_sahkoyhtioihin/6387949 visited 18 June 2013

[54] http://www.ekoenergy.org/how-to-buy-ekoenergy/households/licenseholders/ visited 27 March 2014

[55] http://www.vaihdavirtaa.net/company/list/type/price visited 26 March 2014

[56] http://www.sahkonhinta.fi/ visited 26 March 2014

[57] Del Rio, P., Burguillo M. (2008): Assessing the Impact of Renewable Energy Deployment on Local Sustainability: Towards a Theoretical Framework. Renewable and Sustainable Energy Reviews 12, $1325-1344$

[58] Madlener, R., Vögtli, S. (2008): Diffusion of bioenergy in urban areas: A socio-economic analysis of the Swiss wood-fired cogeneration plant in Basel. Biomass and Bioenergy 32, 815-828

[59] Madlener, R. (2007): Innovation diffusion, public policy, and local initiative: The case of wood-fuelled district heating systems in Austria. Energy Policy 35, 1992-2008

[60] Timmermans, S., Tavory, I. (2012): Theory Construction in Qualitative Research: From Grounded Theory to Abductive, Sociological Theory 30, $167-186$

[61] Tuomi, J., Sarajärvi, A. (2009): Laadullinen tutkimus ja sisällönanalyysi. Helsinki. Tammi 
172 Hast A. et al.

[62] JNS (2012): Kestävästi kasvava älykkäästi uusiutuva. Joensuun kasvustategia (Growth strategy of Joensuu). http://www.pohjoiskarjala.fi/dman/Document.phx/ maakuntaliitto/Julkiset/Tiedotus/ Joensuun+kasvustrategia?folderId $=\sim$ maakuntaliitto $\% 2$ FJulkiset $\% 2$ FTiedotus\&cmd=download

[63] JNS (2010): Joensuun kansainvälistymisstrategia. (International strategy of Joensuu) http://www.joensuu.fi/documents/11127/257171/Kansainv\% C3\%A4lisyystrategia+2009+-+2015/f342ee60-ff75-4763-bd20-3af90e f31f43

[64] PKML (2012a): Pohjois-Karjalan maakuntaliitto Itä-Suomen bioenergiaohjelma 2020 (bioenergy program of North Karelia) pdf document. http://www.pohjois-karjala.fi/dman/Document.phx?documentId=zp3611 $1100930357 \& \mathrm{cmd}=$ download

[65] PKML (2012b): Pohjois-Karjalan ilmasto- ja energiaohjelma. (Climate and Energy Energy Programme of North Karelia). pdf document. http://www.pohjois-karjala.fi/dman/Document.phx?documentId=he249 $11143754662 \& \mathrm{cmd}=$ download

[66] PKML (2012c): Toiminta- ja taloussuunnitelma 2013-2015 sekä tulostavoitteet ja talousarvio (Financial and action strategy 2013.2015 and budjet and budjet goals). 2013. pdf document. http://www.pohjoiskarj ala.fi/dman/Document.phx?documentId=xb00713144310820\&cmd=do wnload

[67] http://www.oecd-ilibrary.org/sites/factbook-2011-en/06/02/03/index.htm 1;jsessionid=1gp3pg5q2xxjb.epsilon?contentType=/ns/Chapter,/ns/Statis ticalPublication\&itemId=/content/chapter/factbook-2011-54-en\&contai nerItemId=/content/serial/18147364\&accessItemIds=\&mimeType=text/ html, visited $2^{\text {nd }}$ of July, 2013.

[68] Polanyi, M. (1998): Personal knowledge: towards a post-critical. Original Version from 1958, corrected in 1962. London. Routledge

[69] Tajfel, H. (1978): Differentiation between social groups: studies in the social psychology of intergroup relations. Edited by Henri Tajfel. London

[70] Del Rio, P., Burguillo M. (2009): An Empirical Analysis of the Impact of Renewable Energy. Renewable and Sustainable Energy Reviews 12, 1325-1344

[71] Putnam, R. (2000): Bowling alone: the collapse and revival of American community. New York. Simon \& Schuster 


\section{Biographies}

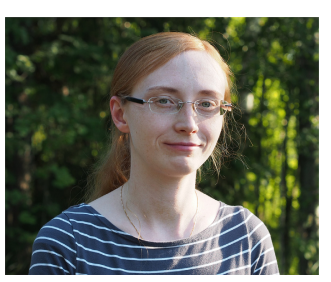

Aira Hast is a Doctoral Student at Aalto University in the Department of Energy Technology. She graduated as a Master of Science (Technology) from Aalto University in 2011 majoring in Systems and Operations Research. She has studied the consumer demand of green energy products in different countries, and also the cost efficiency and uncertainties related to achieving greenhouse gas emission targets in the Finnish non-emission trading sector.

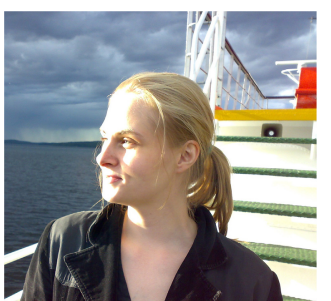

Liisa McDermott is a PhD student of social and public policy from the University of Jyväskylä in Finland. Her research interests are: Social science energy research, elite studies and power relations and local policies of sustainable development. She has done qualitative case study research in Finland and in the USA.

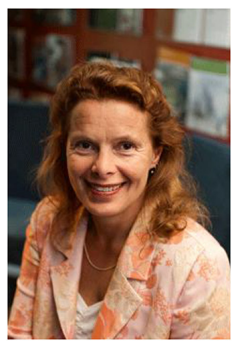

Sanna Syri is professor of energy economics at Aalto University, Department of Energy Technology, since 2010. Before Aalto University, she worked at VTT, The Technical Research Centre of Finland (2002-2010) and at the 


\section{Hast A. et al.}

Finnish Environment Institute (1994-2002). She is expert in analysis of largescale energy systems and in cost-effective mitigation strategies for greenhouse gases and air pollutants.

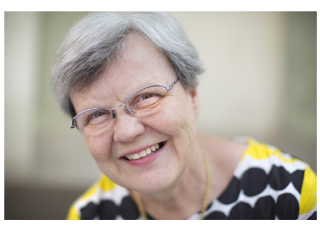

Dr. Marja Järvelä has been Professor in Social and Public Policy at the Department of Social Sciences and Philosophy (University of Jyväskylä) since 1992, and the Head of the disciplinary unit Social and Public Policy since 1997. Her main interest and expertise is in issues of sustainable development, climate change and public governance. Currently she is deputy chair of the Finnish National Climate Change Panel nominated by the Ministry of Environment. She has been leader or partner in charge of several research projects funded e.g. by the Academy of Finland, and the EU/TSER Programme since 1991. She has wide experience of locality studies in Europe, Africa, and Russia. 